\title{
Analisis Usaha Burung Walet di Kecamatan Sinjai Utara Kabupaten Sinjai
}

\author{
Kiki Aryani $^{1}$, Muhammad Erik Kurniawan ${ }^{1 *}$, Andi Kurnia Armayanti ${ }^{1}$ \\ ${ }^{1}$ Program Studi Peternakan, Fakultas Sains dan Teknologi, Universitas Muhammadiyah Sinjai \\ . Jl. Teuku Umar No. 8, Biringere, Sinjai Utara 92611, Sulawesi Selatan, Indonesia \\ *muh.erikkurniawan@ymail.com
}

INFORMASI ARTIKEL

Diterima 17 January 2021

Hasil revisi diterima 24 Juni 2021

Diterbitkan 24 Juni 2021

Publish online 24

Juni 2021

Kata-kata kunci:

Analisis usaha;

Burung Walet;

Lama usaha;

\section{ARTICLE INFO}

Article history

Received 28 January 2021

Received in revised from 24 June 2021 Accepted 24 June 2021

Available online 24 June 2021

Key words:

Business analysis;

Swallow;

Length of business;

\begin{abstract}
ABSTRAK
Penelitian ini bertujuan untuk mengetahui analisis usaha burung walet di Kecamatan Sinjai Utara Kabupaten Sinjai. Jenis penelitian yang digunakan yaitu penelitian kuantitatif dan kualitatif yaitu suatu penelitian yang menjelaskan atau menggambarkan variabel penelitian. Dimana variabel penelitian yang dimaksud yaitu biaya, penerimaan, dan pendapatan Penelitian ini dimulai sejak Mei sampai dengan Juni 2019 di Kecamatan Sinjai Utara Kabupaten Sinjai. Pengumpulan data dilakukan melalui observasi dan wawancara dengan bantuan kuisioner. Hasil penelitian yang diperoleh yaitu rata-rata pendapatan usaha burung walet pada berbagai lama usaha di Kecamatan Sinjai Utara Kabupaten Sinjai adalah pada skala 1 - 2 tahun rata-rata pendapatan yang didapat sebesar Rp. 173.170 213,pertahun, skala 3 - 4 tahun sebesar Rp.642.666.667,-pertahun, dan untuk skala $\geq 5$ tahun sebesar Rp 4.500.000000.
\end{abstract}

This study aims to determine the analysis of swallow business in North Sinjai District, Sinjai Regency. The type of research used is quantitative and qualitative research, namely a study that explains or describes research variables. Where the research variables in question are costs, revenues, and income. This research started from May to June 2019 in North Sinjai District, Sinjai Regency. Data was collected through observation and interviews with the help of questionnaires. The results obtained are the average business income of swallows at various lengths of business in North Sinjai District, Sinjai Regency is on a scale of 1-2 years the average income earned is Rp. 173,170 213,-per year, for a scale of 3 - 4 years, it is Rp. 642,666,667, - per year, and for a scale of 5 years it is Rp. 4.5,000,000. 


\section{PENDAHULUAN}

Pemberdayaan ekonomi rakyat identik dengan pemberdayaan usaha kecil (keluarga), karena secara struktural perekonomian nasional sebagian besar disusun oleh unit-unit skala kecil, yang umumnya bergerak di sektor agroindustri. Selama ini kegiatan usaha kecil hanya memanfaat kan keunggulan komparatif dengan mengandalkan kelimpahan sumber daya yang dimiliki dan hasilnya tidak sesuai dengan harapan. Usaha kecil masih akrab dengan kemiskinan, kare na tingkat pendapatan masih rendah. Keunggulan komparatif harus di dayagunakan menjadi keunggulan kompetitif dengan menentukan kegiatan usaha yang berorientasi pasar. Cara yang ditempuh adalah dengan meningkatkan pangsa pasar dan nilai tambah melalui pemanfaatan modal (capital-driven), pemanfaatan inovasi teknologi (innovationdriven) serta kreativitas sumber daya manusia (skill-driven) (Noverika, 2013).

Komoditas agribisnis yang mempunyai peluang pasar besar ter utama pasar ekspor dan mempunyai nilai ekonomi yang tinggi adalah sarang burung walet. Sarang burung walet merupakan salah satu makanan yang terkenal di dunia Sarang burung walet dipercaya memiliki manfaat yang sangat baik bagi kesehatan tubuh manusia. Karena manfaatnya yang berkhasiat itu maka tidaklah heran jika harganya sangat mahal. Orang Cina sejak ratusan abad yang lalu dikenal sebagai ahli di bidang pengobatan, terutama pengobatan alternatif misalnya tusuk jarum dan ramuan tradisional yang dijual oleh para shinse cukup laris. Bahan ramuan dikombinasikan sesuai dengan jenis penyakit yang akan disembuhkan Salah satu bahan yang digunakan yaitu sarang walet. Sarang burung walet ini diyakini sebagai food suplement yang berkhasiat tinggi untuk menjaga stamina (Budiman, 2008).

Indonesia dikenal memiliki sumber daya alam yang cukup melimpah. Burung walet sebagai salah satu sumberdaya hayati memiliki nilai yang tinggi, baik dari ekologi fauna maupun pengembangan ilmu pengetahuan dan estetika. Burung walet yang kemudian menghasilkan sarang walet secara alamiah banyak dijumpai di gua dalam hutan dan gua-gua yang berada dipinggir-pinggir laut. Selain itu sarang walet juga dapat dihasilkan secara buatan pada suatu bangunan atau gedung. Jenis-jenis burung walet dikenal berbagai macam diantaranya adalah Collocaliamar ginata, Collocalia esculenta, Collo calia brovirostis, Collocatia vaniko rensis, Collocalia fuciphaga, Collo calia troglodytes, Collocaliamaxima dan lain-lain. Sedangkan yang paling sering di perdagangkan sarangnya adalah Collocalia fuciphaga di budidayakan sebagai burung walet, Collocalia esculenta di budidayakan sebagai burung seriti, Collocalia maxima (walet gua hitam). Sarang walet merupakan hasil dari air liur burung walet yang saat ini memiliki nilai ekonomis yang tinggi oleh karenanya dibudidayakan (Mulyono dan Sarwono, 2010).

Usaha sarang burung walet sangat menjanjikan dan memiliki banyak tantangan. Selain harus memiliki modal besar hingga ratusan juta rupiah, peternak harus pandai menge lola rumah walet agar tetap betah dihuni oleh walet, dan jika sudah berhasil menjalankan bisnis ini, uang ratusan juta hingga miliaran rupiah bisa dengan mudahnya ditangan. Harga sarang burung walet Rp .2730 Juta per kg (200 sarang), dengan produksi 5-6 kg sarang walet setiap bulannya sudah terbayang berapa pendapatan yang bisa diperoleh. Hasil dari peternakan walet adalah sarang nya yang terbuat dari air liurnya (saliva). Sarang walet ini selain mempunyai harga yang tinggi, juga dapat bermanfaat bagi dunia kesehatan. Sarang walet berguna untuk menyembuhkan paru-paru, panas dalam melancarkan peredaran darah dan penambah tenaga. Untuk mendapatkan sarang walet bernilai jual tinggi, maka perlu diketahui jenis 
walet yang dapat menghasilkan sarang yang berkualitas baik (Noverika, 2013).

Perkembangan pengetahuan dan teknologi budidaya burung walet sudah sangat meningkat, sarang walet yang dulu hanya biasa diperoleh di gua-gua alami, kini telah dapat dibudidayakan dan burung walet berpindah menghuni bangunan yang khusus dirancang mirip dengan ekosistem gua walet. Bangunan rumah walet tersebut merupakan habitat tempat tinggal buatan yang dirancang khusus untuk burung walet membuat sarangnya pada musim berkembang biak. Bangunan-bangunan rumah walet mulai banyak dibangun baik di tengah kota maupun dipinggiran kota (Sari, 2013). Salah satu daerah yang semakin banyak dijumpai bangunan rumah walet adalah Kecamatan Sinjai Utara Kabupaten Sinjai, untuk lebih jelasnya dapat dilihat pada Tabel 1 .

Ditambahkan oleh Noverika (2013), setiap usaha termasuk usaha burung walet tentunya tidak terlepas dari berbagai resiko, khususnya dalam hal resiko keuangan meskipun jumlah produksinya cukup tinggi. Oleh karena itu petenak burung walet harus mengetahui analisis usaha yang dijalankan, tidak hanya terbatas pada bagaimana memelihara dan membudidayakan burung walet hingga menghasilkan sarang sebagai hasil utama produksi, (Noverika, 2013). Hal inilah yang melatarbelakangi penelitian ini.

Tujuan dari penelitian ini adalah untuk mengetahui analisis usaha burung walet di Kecamatan Sinjai Utara Kabupaten Sinjai.

\section{METODE PENELITIAN}

\section{Lokasi Penelitian}

Lokasi penelitian ini di Kecamatan Sinjai Utara, Kabupaten Sinjai. Alasan memilih lokasi penelitian adalah Kecamatan Sinjai Utara memiliki jumlah pemilik dan pemelihara Burung Walet yang jumlahnya besar di kabupaten Sinjai.

\section{Jenis Penelitian}

Jenis penelitian yang digunakan yaitu penelitian kuantitatif dan kualitatif yaitu suatu penelitian yang men jelaskan atau menggambarkan variabel penelitian. Dimana variabel penelitian yang dimaksud yaitu biaya, penerimaan, dan pendapatan.

\section{Jenis dan Sumber Data}

Jenis data yang digunakan dalam penelitian ini adalah:

1. Data Kuantitatif adalah jenis data yang dapat diukur (measurable) atau dihitung secara langsung sebagai variabel angka atau bilangan. Variabel dalam ilmu statistika adalah atribut, karakteristik, atau pengukuran yang mendeskripsikan suatu kasus atau objek penelitian

2. Data Kualitatif adalah data dari penjelasan kata verbal tidak dapat dianalisis dalam bentuk bilangan atau angka Dalam penelitian, data kualitatif berupa gambaran mengenai objek penelitian. Data kualitatif memberikan dan menunjukkan kualitas objek penelitian yang dilakukan.

Sumber data yang digunakan dalam peneitian ini adalah:

1. Data primer yaitu data yang diperoleh dari hasil pengamatan langsung danwawancara dengan pemilik usaha peternak sarang burung wallet di Kecamatan Sinjai Utara, Kabupaten Sinjal

2. Data sekunder vallu data yang diperoleh dari laporan keuangan, laporan perusahaan dan lain sebagainya.

\section{Populasi dan Sampel}

Populasi merupakan keseluruhan individu pemelihara atau pemilik sarang burung walet yang berada di Kecamatan Sinjai Utara Kabupaten Sinjai. Adapun jumlah total populasi yang berada di Kecamatan Sinjai Utara Kabupaten Sinjai sebanyak 117 
pemelihara yang tersebar di enam kelurahan yaitu Kelurahan Bongki sebanyak 35 pemelihara, Kelurahan Biringere sebanyak 11 pemelihara, Kelurahan Balangnipa sebanyak 40 pemelihara, Kelurahan Lappa sebanyak 18 pemelihara, Kelurahan Alehanuae sebanyak 2 pemelihara, dan Kelurahan Lamatti Rilau sebanyak 3 pemelihara. Berhubung karena jumlah populasi yang cukup besar yaitu 117 pemelihara, maka akan dilakukan pengambilan sampel. Untuk menen tukan besarnya ukuran besarnya ukuran sampel maka akan dilakukan dengan menggunakan statistic deskriptif berdasarkan rumus Slovin menurut Sugiyono (2006) sebagai berikut:

$$
n=\frac{N}{1+N e^{2}}
$$

Keterangan:

$\mathrm{N}=$ Jumlah populas!

$n=$ Jumlah sampel

$\mathrm{E}=$ Tingkat Kelonggaran $(10 \%)$

Sehingga jumlah sampel yang didapatkan yaitu tingkat kelonggaran $10 \%$ digunakan dengan dasar jumlah tidak lebih dari 2000 populasi (Sugiyono, 2003).

Dengan adanya jumlah sampel yang telah ditemukan yaitu 117, maka teknik pengambilan sampelnya digunakan simple random sampling atau dengan cara acak sederhana (random samping).

Dari rumus tersebut, maka dapat diketahui jumlah sampel minimal yang dapat digunakan yaitu :

$$
\begin{aligned}
& n=\frac{117}{1+117(0,1)^{2}} \\
& n=\frac{117}{1+1,17} \\
& n=\frac{117}{2,17}
\end{aligned}
$$

$n=54$ Responden
Sebagai salah satu syarat dalam pengujian hipotesis adalah pengam bilan sama secara random. Teknik penarikan sampel yang dilakukan dari keenam Kelurahan adalah sample random dimana untuk Kelurahan Bongki sebanyak 16 pemelihara, Kelurahan Biringere 6 pemelihara, Kelurahan Balangnipa 22 pemelihara, Kelurahan Lappa 8 pemelihara, Kelurahan Alehanuae 1 pemelihara, dan Kelurahan Lamatti Rilau 2 Pemelihara.

\section{Metode Pengambilan Data}

Metode yang digunakan dalam pengumpulan data pada penelitian ini adalah:

1. Observasi, yaitu pengumpulan data yang dilakukan melalui pengamatan langsung terhadap usaha peternak sarang burung wallet di Kecamatan Sinjal Utara Kabupaten Sinjai

2. Wawancara, yaitu pengumpulan data yang dilakukan melalui wawancara langsung dengan pemilik usaha sarang burung wallet di Kecamatan Sinjai Utara Kabupaten Sinjal

3. Studi Kepustakaan, yaitu berdasarkan beberapa bulu sebagai literature dan landasan teori yang berhubungan dengan penelitian ini.

\section{Analisis Data}

Analisis data yang digunakan dalam penelitian ini adalah :

1. Penerimaan $=\mathrm{TR}=\mathrm{Y}$. $\mathrm{Py}$

$\mathrm{TR}=$ Total Revenue (penerimaan usaha tani).

Y Output (produksi yang diperoleh)

Py - Price (harga output)

2. Pendapatan $=\mathrm{Pd}=\mathrm{TR}-\mathrm{TC}$

$\mathrm{Pd}=$ Total Pendapatan (Rp/tahun)

$\mathrm{TR}=$ Total revenue (Rp/tahun)

$\mathrm{TC}=$ Total Cost (Rp/tahun) 
3. Return Cost Ratio (R/C)

$$
R / C=\frac{\text { total penerimaan penjualan }}{\text { total biaya }}
$$

4. Break Even Point (BEP)

$$
\frac{\text { total biaya tetap }}{\text { (harga jual / unit - biaya variabel / unit }}
$$

\section{Payback Period (PP)}

$$
\begin{aligned}
& P P=\frac{\mathrm{I}}{\mathrm{Ab}} \\
& \mathrm{PP}=\text { Waktu yang diperlukan untuk } \\
& \text { mengembalikan modal (tahun) } \\
& \mathrm{I} \quad=\text { Jumlah modal investasi (Rp) } \\
& \mathrm{Ab}=\text { Manfaat hasil bersih rata-rata per } \\
& \quad \text { tahun periode (Rp) }
\end{aligned}
$$

\section{HASIL DAN PEMBAHASAN}

\section{Biaya Produksi}

\section{Biaya Tetap}

Biaya tetap merupakan komponen terakhir dalam biaya operasional setelah biaya variabel. Tidak seperti variabel besaran biaya tetap yang dikeluarkan tidak dipengaruhi jumlah ternak yang dijual. Komponen tersebut hanya berupa penyusutan peralatan dan penyusutan kandang.

\section{Biaya Variabel}

Biaya variabel merupakan salah satu komponen biaya operasional dalam kegiatan bisnis. Biaya variabel yang dikeluarkan oleh para pengusaha baik itu usaha yang berskala kecil, menengah hingga besar terdiri dari biaya parfum, pakan, dan obat-obatan.

\section{Penerimaaan dan Pendapatan Penerimaan}

Penerimaan adalah hasil perkalian jumlah produksi dengan harga jual. Bentuk umum penerimaan dari penjualan yaitu $T R=P \times Q$, dimana TR adalah total revenue atau penerimaan, $\mathrm{P}$ adalah Price atau harga jual perunit produk dan Q adalah Quantity atau jumlah produk yang dijual.

Tabel 1. Data lokasi pemeliharaan burung walet di kecamatansinjai Utara Kabupaten Sinjai.

\begin{tabular}{clc}
\hline No. & \multicolumn{1}{c}{ Letak / Lokasi } & Jumlah \\
\hline 1. & Kelurahan Bongki & 35 \\
2. & Kelurahan Biringere & 11 \\
3. & Kelurahan Balangnipa & 48 \\
4. & Kelurahan Lappa & 18 \\
5. & Kelurahan Alehanuae & 2 \\
6. & Kelurahan Lamatti Rilau & 3 \\
\hline Kecamatan Sinjai & 117 \\
\hline
\end{tabular}

\section{Pendapatan}

Pendapatan yaitu selisih dari total penerimaan dengan total biaya dengan rumus $\mathrm{Pd}=\mathrm{TR}-\mathrm{TC}$, dimana Pd adalah Pendapatan, TR yaitu total penerimaan dan TC adalah total biaya. Adapun total pendapatan yang diterima oleh para pengusaha berdasarkan jumlah kepemilikan usaha di Kecamatan Sinjai Utara Kabupaten Sinjai dapat dilihat pada Tabel 2.

Pada tabel 2 dapat diketahui berdasarkan lama usaha biaya, penerimaan dan pendapatan. Lama usaha 1-2 tahun dengan biaya yang yang digunakan biaya tetap sebesar Rp 30.473.095 dan biaya variabel Rp. 2.547. 128 sehingga hasil dari penerimaan usaha sejumlah Rp. 140.149.990, adapun total hasil pendapatan yang diperoleh sejumlah $\mathrm{Rp}$. 173.170.213. Pada lama usaha 3-4 tahun dengan biaya tetap yang dikeluarkan $\mathrm{Rp}$ 27.021.444 dan biaya variabel yang dikeluarkan Rp. 3.055.000 sehingga hasil penerimaan yang didapatkan sejumlah Rp. 612.590.992. Adapun total hasil pendapatan yang di terima sejumlah Rp. 642.666.667 sedangkan pada lama usaha diatas 5 tahun biaya tetap Rp.23.960.000, biaya variabel $R p$. 5.370.000, sedangkan hasil penerimaan yang diperoleh Rp. 4.470.670 .000 dan total hasil pendapatan yang di peroleh Pengusaha Burung walet sejumlah Rp 4.500.000.000. 
Hal ini sesual pendapat Utamy (2013) yang menyatakan bahwa biaya tetap atau biasa disebut fixed cost adalah biaya yang umumnya selalu konstan. bahkan di masa sulit. Biaya tetap tidak terpengaruh oleh perubahan-perubahan dalam aktivitas operasi sampai pada kondisi tertentu. kondisi dimana sesuai dengan kapasitas yang tersedia untuk mengetahui rincian yang diperoleh dari nilai total biaya tetap yang dikeluarkan oleh pengusaha burung walet dan Biaya variabel atau juga disebut variable cost adalah biaya yang umumnya berubah-ubah sesuai dengan volume bisnis. Makin besar volume penjualan. makin besar pula biaya yang harus dikeluarkan Rasyaf (2003) menerangkan batwa pendapatan adalah sejumlah uang yang diperoleh setelah semua biaya variabel dan biaya tetap tertutupi. Hasil pengurangan positif berarti untung. hasil pengurangan negatif berarti rugi.

\section{Return Cost Ratio (R/C)}

$\mathrm{R} / \mathrm{C}$ adalah perbandingan antara penerimaan penjualan dengan biaya-biaya yang dikeluarkan selama proses produksi hingga menghasilkan produk. Usaha burung walet dengan berbagai skala usaha di Kecamatan Sinjai Utara Kabupaten sinjai akan menguntungkan apabila nilai R/C > 1 .
Semakin besar nilai R/C semakin besar pula tingkat keuntungan yang akan diperoleh dari usaha tersebut. Adapun return cost ratio yang diperoleh para pengusaha burung walet berdasarkan jumlah kepemilikan usaha di Kecamatan Sinjai Utara Kabu paten Sinjai dapat dilihat pada Tabel 3.

Pada tabel 3 dapat diketahui berdasarkan lama usaha memiliki nilai $\mathrm{R} / \mathrm{C}>1$ terlihat pada lama usaha 1-2 tahun jumlah $\mathrm{R} / \mathrm{C}$ yang didapatkan 5.23 pada skala usaha 3-4 tahun R/C yang diperoleh 21.59 dan pada skala usaha di atas 5 tahun $\mathrm{R} / \mathrm{C}$ yang diperoleh 153.43. Hal ini sesuai dengan pendapat Soekartawi (2002) yang menyatakan bahwa R/C adalah singkatan dari Retum Cost Ratio atau dikenal sebagai perbandingan (nisbah) antara Penerimaan dan biaya. Kriteria uji : Jika R/C $>1$. layak untuk diusahakan. jika R/C $<1$ maka tidak layak untuk diusahakan.

\section{Break Event Point (BEP)}

Analisa ini menggunakan pendekatan untuk penentuan jumlah barang yang dijual pada harga tertentu untuk menutupi biaya yang ada karena transaksi tersebut Adapun break even point yang diperoleh para pengusaha walet berdasarkan jumlah kepemilikan usaha di Kecamatan Sinjai Utara Kabupaten Sinjai dapat dilihat pada Tabel 4.

Tabel 2. Total Biaya Tetap, Biaya Variabel, Penerimaan dan Pendapatan Pengusaha Burung Walet di Kecamatan Sinjai Utara Kabupaten Sinjai.

\begin{tabular}{cccccc}
\hline \multirow{2}{*}{ No. } & $\begin{array}{c}\text { Lama Usaha } \\
(\text { Tahun })\end{array}$ & $\begin{array}{c}\text { Biaya Tetap } \\
(\mathrm{Rp})\end{array}$ & $\begin{array}{c}\text { Biaya Variabel } \\
(\mathrm{Rp})\end{array}$ & $\begin{array}{c}\text { Penerimaan } \\
(\mathrm{Rp})\end{array}$ & $\begin{array}{c}\text { Pendapatan } \\
(\mathrm{Rp})\end{array}$ \\
\hline 1. & $1-2$ & 30.473 .095 & 2.547 .128 & 140.149 .990 & 173.170 .213 \\
2. & $3-4$ & $27,021.444$ & 3.055 .000 & 612.590 .222 & 642.666 .667 \\
3. & $\geq 5$ & 23.960 .000 & 5.370 .000 & 4.470 .670 .000 & 4.500 .000 .000 \\
\hline
\end{tabular}

Tabel 3. Total Biaya Return Cost Ratio Pengusaha Burung Walet di Kecamatan Sinjai Utara Kabupaten Sinjai.

\begin{tabular}{ccccc}
\hline No & Lama Usaha (Tahun) & Total Penerimaan $(\mathrm{Rp})$ & Total Biaya $(\mathrm{Rp})$ & $\mathrm{R} / \mathrm{C}$ \\
\hline 1. & $1-5$ & 140.149 .990 & 33.020 .223 & 5.23 \\
2. & $3-4$ & 612.590 .222 & 30.076 .444 & 21.59 \\
3. & $\geq 5$ & 4.470 .670 .000 & 29.330 .000 & 153.43 \\
\hline
\end{tabular}


.Tabel 4. Total Biaya Break Even point (BEP) Pengusaha Burung Walet di Kecamatan Sinjai Utara Kabupaten Sinjai.

\begin{tabular}{ccccc}
\hline No & Nama & Total Pendapatan $(\mathrm{Rp})$ & Total Biaya Tetap $(\mathrm{Rp})$ & BEP \\
\hline 1. & Asri & 188.709 .333 & 16.335 .667 & 2 \\
2. & Muhsin & 104.492 .333 & 23.262 .667 & 3 \\
3. & Ahmad & 140.042 .000 & 31.643 .000 & 3 \\
\hline
\end{tabular}

Tabel 5. Payback Period (PP) Pengusaha Burung Walet di Kecamatan Sinjai Utara Kabupaten Sinjai.

\begin{tabular}{ccccc}
\hline No & Nama & Jumlah Modal Investasi (Rp) & PP (Tahun) & Jangka Pengembalian Modal \\
\hline 1. & Asri & 54.250 .000 & 0,20 & 20 Bulan \\
2. & Muhsin & 98.700 .000 & 0,36 & 36 Bulan \\
3. & Ahmad & 143.750 .000 & 0,53 & 53 Bulan \\
\hline
\end{tabular}

Tabel 4 dapat dilihat perwakilan dari usaha burung walet dan skala usaha. Pada skala kecil diwakilkan oleh Bapak Asri dengan pendapatan Rp.188.709.333 dengan total biaya tetap Rp. 16.335.667 dengan BEP 2 . Pada skala menengah diwakili oleh Bapak Muhsin dengan pendapatan Rp. 104.492333 dengan total biaya Rp. 23.262.667 dengan BEP 3. Sedangkan pada skala besar diwakili oleh Bapak Ahmad dengan pendapatan Rp. 140.042.000 dengan total biaya $\mathrm{Rp}$ 31.643.000 dengan BEP 3.

\section{Payback Period (PP)}

Payback Period merupakan jangka waktu pengembalian investasi yang dikeluarkan. melalui keuntungan yang diperoleh dari suatu proyek (Umar. 2003). Semakin pendek waktu yang dibutuhkan untuk mengembalikan nilai investasi yang dikeluarkan maka bisnis semakin layak diusahakan. Adapun payback period yang diperoleh para pengusaha burung walet berdasarkan jumlah kepemilikan usaha di Kecamatan Sinjai Utara Kabupaten Sinjal dapat dilihat pada Tabel 5.

Pada tabel 5 dapat dilihat payback period yang diterima oleh pengusaha burung walet baik skala kecil. menengah. dan besar sangat berbeda-beda. mulai dari skala kecil payback period yang didapatkan yaitu 0.20 dengan jangka waktu pengembalian modal yakni 20 bulan. pada skala usaha menengah payback period yang diterima yakni 0.36 dengan jangka waktu pengembalian 36 bulan. sedangkan skala usaha besar payback period yang diterima yaitu 0.53 dengan jangka waktu 53 bulan. Hal ini sesuai dengan pendapat Rangkuti (2011) yang menyatakan bahwa payback period adalah suatu periode yang diperlukan untuk menutup kembali pengeluaran investasi (initial cash investment) yang menggunakan aliran kass. dengan kata lain PP merupakan rasio antara initial cash investment dengan cash inflow-nya. yang hasilnya merupakan satuan waktu. Selanjutnya nilai rasio ini dibandingkan dengan maksimum PP yang dapat diterima.

\section{KESIMPULAN}

Kesimpulan penelitian ini adalah ratarata pendapatan pengusaha burung walet pada berbagai lama usaha di Kecamatan Sinjai Utara Kabupaten Sinjai adalah pada skala 1-2 tahun rata-rata pendapatan yang didapat sebesar Rp. 173.170.213.- per tahun, skala 3-4 tahun sebesar Rp. 642.666.667,-- per tahun dan untuk skala $\geq 5$ tahun sebesar $\mathrm{Rp}$ 4.500.000.000. Perbedaan pendapatan/ keuntungan yang diperoleh pengusaha 
berbeda-beda dipengaruhi perbedaan jumlah hasil panen.

\section{DAFTAR PUSTAKA}

Budiman, A. (2008). Budidaya dan Bisnis Sarang Walet. Jakarta: Penebar Swadaya

Mulyono, S., \& Sarwono, B. (2010). Penggemukan Kambing Potong. Jakarta: Penebar Swadaya.

Noverika, A. (2013). Analisis Pendapatan Peternak Sarang Burung Walet UD. Putra Bahagia Kelurahan Maccege Kecamatan Tanete Riantang Kabupater Bone. Skripsi. Makassar: Universitas Hasanuddin.

Rangkuti, F. (2011). Riset Pemasaran. Jakarta: Gramedia Pustaka Utama.

Rasyaf. (2003). Memasarkan Hasil Peternakan. Jakarta: Penebar Swadaya.
Sari, R.P. (2013). Persepsi Masyarakat Terhadap Keberadaan Burung Walet di Kelurahan Macege, Kecamatan Tanete Riattang Kabupaten Bone. Skripsi. Makassar: Universitas Hasanuddin.

Soekartawi. (2002). Analisis Usaha Tani. Jakarta: UI-Press.

Sugiyono. (2003). Statistika Untuk Penelitian. Bandung: Alfabeta. B

Sugiyono. (2006). Metode Penelitian Kuantitatif Kualitatif dan R\&D. Bandung: Alfabeta.

Umar. (2003). Analisis Ekonomi ProyekProyek Pertanian. Edisi Kedua. Jakarta: UI Press.

Utamy, R.S. (2013). Defenisi dan Contoh Biaya Tetap, Biaya Variabel dan Semi Variabel.http://rahmisetyautamy.blogsp o .com/2013/03/definisi-dan-contohbiaya-tetap html. 